\title{
Resistance of Gardnerella vaginalis to bactericidal activity of human serum
}

\author{
Y L BOUSTOULLER AND A P JOHNSON
}

\section{From the Division of Sexually Transmitted Diseases, MRC Clinical Research Centre, Harrow, Middlesex}

SUMMARY To assess the sensitivity of Gardnerella vaginalis to the complement mediated bactericidal activity of serum, six laboratory strains were incubated with normal human serum and two strains freshly isolated from women with non-specific vaginitis (NSV) were each incubated with homologous patient serum. There was no significant difference between the number of organisms recovered from unheated or heat inactivated serum after incubation at $37^{\circ} \mathrm{C}$ for one hour with any of the strains tested. A suspension of $G$ vaginalis incubated at $37^{\circ} \mathrm{C}$ for one hour in heat inactivated homologous mouse antiserum with unheated normal human serum as a source of complement did not show any less viability than the control mixture using heat inactivated human serum. In contrast, a serum resistant strain of Neisseria gonorrhoeae incubated in heat inactivated homologous mouse antiserum with unheated normal human serum showed noticeably less viability than the control. $G$ vaginalis therefore seems to be resistant to the bactericidal activity of both normal and immune serum.

\section{Introduction}

In 1955 Gardner and Dukes ${ }^{1}$ reported isolating a bacterium now classified as Gardnerella vaginalis ${ }^{2}$ from $92 \%$ of women suffering from non-specific vaginitis (NSV), a condition characterised by the presence of a foul smelling vaginal discharge, an elevated vaginal $\mathrm{pH}$ value $(\geq 5.0)$, and the presence of clue cells, which are epithelial cells covered with coccobacilli. Gardner and Dukes ${ }^{1}$ thought that the micro-organism they had described was the causative agent of NSV as they failed to isolate it from women not suffering from this condition. Subsequent reports that $G$ vaginalis may be isolated from women without NSV, ${ }^{3-6}$ however, together with the observation that there is an increase in the anaerobic vaginal flora of women with NSV, ${ }^{67}$ cast doubts on the aetiological role of $G$ vaginalis in this disease.

Though the role of $G$ vaginalis in the pathogenesis of NSV is not clear, there is increasing evidence that it may be a cause of extravaginal infection. In 1971 Platt presented evidence of two cases of neonatal infection due to $G$ vaginalis. ${ }^{8}$ The bacterium was isolated from lesions on the scalp of one child and was recovered

\footnotetext{
Address for reprints: Dr Y L Boustouller, Division of Sexually Transmitted Diseases, Clinical Research Centre, Watford Road, Harrow, Middlesex HA1 3UJ
}

Accepted for publication 9 April 1986 from the blood of the other child who died within six hours. When reviewing other cases of neonatal infection, Platt reported that $G$ vaginalis had been isolated from maternal and cord blood, as well as from maternal vaginal specimens, though some isolates were from patients undergoing abortion where uterine trauma may have accounted for the organism entering the vascular system. ${ }^{8}$

Bacteraemia due to $G$ vaginalis has been reported in obstetric patients by Carney ${ }^{9}$ and Monif and Baer, ${ }^{10}$ who also isolated the bacterium from cord blood. More recently, a case of $G$ vaginalis sepsis in an obstetric patient was reported by LaScolea et al. ${ }^{11}$ Other evidence of extravaginal infection has been reported by Venkataramani and Rathbun, ${ }^{12}$ who presented clinical data on 29 cases of bacteremia due to $G$ vaginalis, and by Malone et al, ${ }^{13}$ who obtained $G$ vaginalis from an abdominal incision, abdominal fluid, Bartholin's cysts, blood, and vaginal abscesses, as well as from pharyngeal culture. On investigating the association of NSV with complications after or during pregnancy, Eschenbach et al linked the bacteria found in patients with NSV, particularly $G$ vaginalis, with prematurity and postpartum endometritis. ${ }^{14}$

With these thoughts in mind, we undertook an investigation to examine the resistance of $G$ vaginalis to the bactericidal activity of serum, as such a property may enhance the ability of the bacteria to cause infection. 


\section{Materials and methods}

\section{BACTERIA}

We used six laboratory strains $(3.1,39.2,8821,6376$, 662 and 673) of $G$ vaginalis, one strain (319) isolated from cord blood, and two strains ( 762 and 763 ) freshly isolated from women with NSV. The organisms were cultured on Columbia agar plates containing $10 \%$ (v/v) defibrinated sheep blood (Difco) incubated at $37^{\circ} \mathrm{C}$ in an atmosphere of $5 \%$ carbon dioxide $(\mathrm{v} / \mathrm{v})$ in air. All strains were stored at $-70^{\circ} \mathrm{C}$ in thioglycollate broth containing $10 \%(\mathrm{v} / \mathrm{v})$ glycerol and $10 \%(\mathrm{v} / \mathrm{v})$ defibrinated horse blood. The strains were identified as $G$ vaginalis on the basis that after 48 hours growth they were all Gram variable coccobacilli that gave a negative result on the oxidase and catalase tests, produced $\beta$ haemolysis on human blood polysorbate (Tween) 80 medium, ${ }^{15}$ failed to grow on nutrient agar, and were sensitive to trimethoprim $(5 \mathrm{mg} / \mathrm{l}) .{ }^{16}$ All the strains were biotyped according to the scheme described by Piot et al. ${ }^{17}$

We also used a strain (30866) of $N$ pharyngis known to be susceptible to killing by normal human serum $^{18}$ and a serum resistant strain $(203 \mathrm{H})$ of $N$ gonorrhoeae isolated from the urethra of a man with gonococcal urethritis. The organisms were cultured on GC agar base (Difco) supplemented with $2 \%$ (v/v) IsoVitalex (BBL) at $37^{\circ} \mathrm{C}$ in an atmosphere of $5 \%$ carbon dioxide $(\mathrm{v} / \mathrm{v})$ in air, and were stored in defibrinated sheep blood at $-70^{\circ} \mathrm{C}$.

\section{HUMAN SERUM SAMPLES}

We obtained blood samples from three volunteers on the staff of the Clinical Research Centre (CRC) and from two patients diagnosed as having NSV. The collection of blood samples was approved by the ethics committee. Each sample was allowed to clot at room temperature for 30 minutes then kept at $4^{\circ} \mathrm{C}$ for another 30 minutes, after which the serum was separated by centrifugation and stored in small aliquots at $-70^{\circ} \mathrm{C}$. Each vial was thawed once, and any serum remaining after the experiment was discarded. Assays of haemolytic complement activity (performed by the division of immunological medicine, CRC) showed that all serum samples had normal levels of activity.

\section{MOUSE ANTISERA}

Antisera to $G$ vaginalis (strain 6376 ) and to $N$ gonorrhoeae (strain $203 \mathrm{H}$ ) were prepared in mice using the method described by Wang et al, ${ }^{19}$ except that the $G$ vaginalis organisms were not treated with formalin. To prepare antigens, $G$ vaginalis was grown for $\mathbf{4 8}$ hours as described above, after which the growth was removed from the agar surface using a bacteriological loop and suspended in sterile phosphate buffered saline (PBS) at a concentration of
$1 \times 10^{5}$ colony forming units $(\mathrm{cfu}) / \mathrm{ml}$. Gonococci were grown overnight as described above, harvested into sterile PBS at a concentration of $2 \times 10^{7} \mathrm{cfu} / \mathrm{ml}$, and treated with formalin. ${ }^{19}$ Mice were inoculated intravenously with $0.2 \mathrm{ml}$ of each bacterial suspension, and the inoculation was boosted seven days later using freshly prepared suspensions. Three days after that the mice were exsanguinated by bleeding from the axilla.

We tested the serum samples for antibodies to $G$ vaginalis and $N$ gonorrhoeae by a microimmunofluorescence technique, ${ }^{19}$ modified by not formalising the $G$ vaginalis antigens. In brief, the bacteria were suspended in PBS at a concentration of 1 $\times 10^{8} \mathrm{cfu} / \mathrm{ml}$ and mixed with an equal volume of $7 \%$ (w/v) yolk sac. Antigen dots were applied, using a mapping pen, to the wells of slides coated with Klingerflon spray (Marshall-Howlett, Kent). The antigen dots were air dried, fixed with acetone, and overlayed with serial dilutions of mouse antiserum. After incubation at $37^{\circ} \mathrm{C}$ in a moist chamber for one hour, the slides were washed in PBS and overlayed with rabbit anti-mouse immunoglobulin (Miles) conjugated with fluorescein. The slides were incubated as above for one hour, washed in PBS, dried in air, and examined under an epifluorescence microscope. The antibody titre was recorded as the highest dilution of serum at which the bacteria fluoresced.

\section{BACTERICIDAL ASSAY}

Bacteria were grown as described above and suspended in sterile PBS. Clumps of bacteria were broken up using a needle and syringe, and the numbers of viable organisms were assessed by titration. To estimate the effect of human serum on bacterial survival, $20 \mu$ l of each suspension was mixed with $180 \mu \mathrm{l}$ of unheated or heat inactivated (at $56^{\circ} \mathrm{C}$ for 30 minutes) undiluted human serum and incubated at $37^{\circ} \mathrm{C}$ for one hour. The mixtures were then diluted tenfold in PBS, and $10 \mu \mathrm{l}$ of each dilution was put on to the appropriate solid medium for the number of viable organisms to be counted. The susceptibility of the bacteria to the bactericidal activity of serum was assessed by comparing the numbers of organisms surviving in unheated and heat inactivated homologous serum. In two experiments designed to study the susceptibility or resistance of $G$ vaginalis and $N$ gonorrhoeae to killing by specific antibody and complement, the above procedure was modified by replacing the $180 \mu$ l of normal human serum with a mixture of equal volumes $(90 \mu \mathrm{l})$ of heat inactivated specific mouse antiserum and either unheated or heat inactivated human serum.

\section{Results}

SURVIVAL OF G VAGINALIS IN HUMAN SERUM To assess the susceptibility or resistance of $G$ 
TABLE I Survival of Gardnerella vaginalis, Neisseria pharyngis, and $\mathrm{N}$ gonorrhoeae after incubation for one hour at $37^{\circ} \mathrm{C}$ with unheated or heat inactivated human serum

\begin{tabular}{|c|c|c|c|c|c|}
\hline \multirow[b]{2}{*}{ Organism } & \multirow[b]{2}{*}{ Strain No } & \multirow[b]{2}{*}{$\begin{array}{l}G \text { vaginalis } \\
\text { biotype No }\end{array}$} & \multirow[b]{2}{*}{$\begin{array}{l}\text { No of organisms } / \mathrm{ml}\left(\log _{10}\right) \\
\text { in mixture at zero time }\end{array}$} & \multicolumn{2}{|c|}{$\begin{array}{l}\text { No of organisms } / \mathrm{ml}\left(\log _{10}\right) \text { recovered } \\
\text { after incubation with: }\end{array}$} \\
\hline & & & & $\begin{array}{l}\text { Unheated } \\
\text { human serum }\end{array}$ & $\begin{array}{l}\text { Heat inactivated } \\
\text { human serum }\end{array}$ \\
\hline$G$ vaginalis & 3.1 & 2 & $7 \cdot 9$ & $7 \cdot 6$ & $7 \cdot 5$ \\
\hline$G$ vaginalis & 39.2 & 1 & $7 \cdot 9$ & $8 \cdot 4$ & $7 \cdot 9$ \\
\hline$G$ vaginalis & 8821 & 2 & $7 \cdot 5$ & 6.9 & $6 \cdot 7$ \\
\hline$G$ vaginalis & 6376 & 3 & $6 \cdot 4$ & $6 \cdot 7$ & $7 \cdot 0$ \\
\hline$G$ vaginalis & 662 & 8 & $7 \cdot 9$ & $8 \cdot 0$ & $8 \cdot 2$ \\
\hline$G$ vaginalis & 673 & 1 & $7 \cdot 3$ & $7 \cdot 7$ & $7 \cdot 0$ \\
\hline$G$ vaginalis & 319 & 1 & $7 \cdot 2$ & $7 \cdot 7$ & $7 \cdot 6$ \\
\hline$N$ pharyngis & 30866 & & $7 \cdot 7$ & $5 \cdot 4$ & $7 \cdot 6$ \\
\hline$N$ gonorrhoeae & $203 \mathrm{H}$ & & $6 \cdot 8$ & $7 \cdot 1$ & $7 \cdot 1$ \\
\hline$G$ vaginalis & $762^{*}$ & 1 & $7 \cdot 7$ & $7 \cdot 7$ & $7 \cdot 8$ \\
\hline$G$ vaginalis & $763^{*}$ & 2 & $7 \cdot 7$ & $8 \cdot 0$ & $8 \cdot 0$ \\
\hline
\end{tabular}

*Strains 762 and 763 were tested using homologous patient serum.

vaginalis to the bactericidal activity of human serum, seven strains were tested in duplicate using each of the three normal human serum samples, and two strains were tested in duplicate against their homologous patient serum samples. The biotypes of these strains are shown in table I. In the experiments using each of the three human serum samples (the results of one of which are shown in table I) $G$ vaginalis was resistant to killing, as equivalent numbers of organisms were recovered from unheated and heat inactivated homologous serum after incubation for one hour at $37^{\circ} \mathrm{C}$. Similar results were obtained when the other two serum samples were used (data not shown). This was in strong contrast to the results obtained with $N$ pharyngis, an organism known to be sensitive to serum, where the number of organisms surviving in unheated serum was less than $0.6 \%$ of that seen in heat inactivated serum (table I). These control organisms were not killed by the alternative pathway, as no killing could be seen in the presence of $10 \mathrm{mmol} / 1$ magnesium ethylene glycol tetra-acetic acid (Mg-EGTA) ${ }^{20}$ in the unheated serum. Using serum samples from two women diagnosed as having NSV, the homologous $G$ vaginalis isolates (strains 762 and 763 ) also seemed to be resistant to the bactericidal activity of the serum.
SURVIVAL OF G VAGINALIS AND $N$ GONORRHOEAE IN THE PRESENCE OF SPECIFIC ANTIBODY AND COMPLEMENT

To assess the effect of specific antibody and complement on the survival of $G$ vaginalis (strain 6376) and $N$ gonorrhoeae (strain $203 \mathrm{H}$ ), organisms were incubated in the presence of heat inactivated homologous mouse antiserum mixed with human serum as a source of complement. Control mixtures were identical except that the human serum was heated to inactivate complement. In addition, in one experiment organisms were mixed with the heterologous antiserum and complement. The titres of the mouse antisera to $G$ vaginalis and $N$ gonorrhoeae were $1 / 512$ and $1 / 1024$ respectively as measured by microimmunofluorescence, there being no serological cross reactions between these organisms. The mouse antiserum to $N$ gonorrhoeae was therefore diluted twofold so that the antibody titres in the test were comparable. In each of two experiments (the results of one of which are shown in table II) the data showed that $G$ vaginalis was not only resistant to killing by normal human serum (table I) but was completely resistant to killing by specific antibody and complement, as identical numbers of organisms were recovered from unheated and heat inactivated serum

TABLE II Survival of Gardnerella vaginalis and Neisseria gonorrhoeae after incubation for one hour at $37^{\circ} \mathrm{C}$ with homologous heat inactivated mouse antiserum supplemented with unheated or heat inactivated human serum

\begin{tabular}{|c|c|c|c|c|}
\hline \multirow[b]{2}{*}{ Organism } & \multirow[b]{2}{*}{ Strain No } & \multirow[b]{2}{*}{$\begin{array}{l}\text { No of organisms } / \mathrm{ml}\left(\log _{10}\right) \\
\text { in mixture at zero time }\end{array}$} & \multicolumn{2}{|c|}{$\begin{array}{l}\text { No of organisms } / \mathrm{ml}\left(\log _{10}\right) \text { recovered } \\
\text { after incubation with homologous antiserum } \\
\text { supplemented with: }\end{array}$} \\
\hline & & & $\begin{array}{l}\text { Unheated } \\
\text { human serum }\end{array}$ & $\begin{array}{l}\text { Heat inactivated } \\
\text { human serum }\end{array}$ \\
\hline $\begin{array}{l}G \text { vaginalis } \\
N \text { gonorrhoeae }\end{array}$ & $\begin{array}{l}6376 \\
203 \mathrm{H}\end{array}$ & $\begin{array}{l}6 \cdot 7 \\
6 \cdot 5\end{array}$ & $\begin{array}{l}7 \cdot 0 \\
2 \cdot 7\end{array}$ & $\begin{array}{l}7 \cdot 0 \\
6 \cdot 6\end{array}$ \\
\hline
\end{tabular}


(table II). This was in contrast to the results obtained with $N$ gonorrhoeae strain $203 \mathrm{H}$, which was resistant to killing by normal human serum (table I) but which exhibited a pronounced decrease in viability in the presence of specific antibody and complement. The reduction in the number of viable organisms, as judged by colony counts, was due to killing of the organisms and not to clumping, as the latter was not seen on Gram staining. The loss of viability of the gonococcus was only seen with the homologous, but not the heterologous antiserum, which indicated that this was a specific reaction. This specificity was further confirmed by the observation that the anti-gonococcal antiserum had no effect on the viability of the $G$ vaginalis.

$G$ vaginalis and $N$ pharyngis behaved in the same way as described previously when the above experiments were undertaken using guinea pig serum diluted $1: 10$ as the source of complement in place of human serum.

\section{Discussion}

The results presented here show that $G$ vaginalis is resistant to the bactericidal activity of both normal and immune serum. The survival of $G$ vaginalis in serum could not be explained by a deficiency in complement, as all the serum samples had normal levels of haemolytic complement activity and were capable of killing an organism known to be sensitive to serum by the classical pathway. The mechanism by which $G$ vaginalis resists killing by serum is not currently known and awaits further immunochemical and structural analysis of the cell wall. The structure of the cell wall of $G$ vaginalis has been the subject of much controversy, some workers describing it as Gram positive and others as Gram negative, ${ }^{21} 22$ though the observed property of serum resistance is a feature more commonly associated with Gram positive bacteria.

Though the role of $G$ vaginalis in NSV is not clear, there is increasing evidence that it may cause pregnancy associated, post partum, and neonatal infection. ${ }^{14}$ The pathogenesis of such infections is not understood, but the results presented here show that $G$ vaginalis is resistant to the bactericidal activity of serum, a property that may be important in the development of invasive or systemic infections by this micro-organism.

YLB is in receipt of an MRC scholarship for training in research methods. We thank Dr C Ison and the staff at the Praed Street Clinic (St Mary's Hospital, London) for providing strains $662,673,319,762$, and 763, and Ms E Taylor (St Thomas's Hospital, London) for providing strains 3.1, 39.2, 8821, and 6376. We also thank Dr D Taylor-Robinson for his guidance.

\section{References}

1. Gardner HL, Dukes CD. Haemophilus vaginalis vaginitis. Am J Obstet Gynecol 1955;69:962-76.

2. Greenwood JR, Pickett MJ. Transfer of Haemophilus vaginalis (Gardner and Dukes) to a new genus. Gardnerella: $G$ vaginalis ( $G$ ardner and Dukes) comb nov. International Journal of Systematic Bacteriology 1980;30:170-8.

3. Levison ME, Corman LC, Carrington ER, Kaye D. Quantitative microflora of the vagina. Am J Obstet Gynecol 1977;127:80-5.

4. Levison ME, Trestman I, Quach R, Sladowski C, Floro CN. Quantitative bacteriology of the vaginal flora in vaginitis. $\mathrm{Am} \mathrm{J}$ Obstet Gynecol 1979;133:139-44.

5. McCormack WM, Hayes $\mathrm{CH}$, Rosner B, et al. Vaginal colonization with Corynebacterium vaginale (Haemophilus vaginalis). $J$ Infect Dis 1977;136:740-5.

6. Spiegel CA, Amsel R, Eschenbach D, Schoenknecht F, Holmes KK. Anaerobic bacteria in nonspecific vaginitis. $N$ Engl J Med 1980;303:601-7.

7. Taylor E, Blackwell AL, Barlow D, Phillips I. Gardnerella vaginalis, anaerobes and vaginal discharge. Lancet 1982;: 1376.

8. Platt MS. Neonatal Haemophilus vaginalis (Corynebacterium vaginalis) infection. Clin Pediatr (Phila) 1971;10:513-6.

9. Carney FE. Haemophilus vaginalis septicemia. Obstet Gynecol 1973;41:78-9.

10. Monif GRG, Baer H. Haemophilus (Corynebacterium) vaginalis septicemia. Am J Obstet Gynecol 1974;121:10415.

11. LaScolea LJ, Dryja DM, Dillon WP. Recovery of Gardnerella vaginalis from blood by the quantitative direct plating method. $J$ Clin Microbiol 1984;20:568-9.

12. Venkataramani TK, Rathbun HK. Corynbebacterium vaginale (Haemophilus vaginalis) bacteremia; clinical study of 29 cases. John Hopkins Medical Journal 1976;139:93-7.

13. Malone BH, Schreiber M, Schneider NJ, Holdemann LV. Obligately anaerobic strains of Corynebacterium vaginale (Haemophilus vaginalis). J Clin Microbiol 1975;2:272-5.

14. Eschenbach DA, Gravett MG, Chen KCS, Hoyme UB, Holmes KK. Bacterial vaginosis during pregnancy. In: Mårdh P-A and Taylor-Robinson D, eds. Bacterial vaginosis. Stockholm: Almqvist and Wiksell. 1984;213.

15. Totten PA, Amsel R, Hale J, Piot P, Holmes KK. Selective differential human blood bilayer media for isolation of Gardnerella (Haemophilus) vaginalis. J Clin Microbiol 1982:15:141-7.

16. Taylor E, Phillips I. The identification of Gardnerella vaginalis. J Med Microbiol 1983;16:83-92.

17. Piot P, Van Dyck E, Peeters M, Hale J, Totten PA, Holmes KK. Biotypes of Gardnerella vaginalis. J Clin Microbiol 1984;20:677-9.

18. Johnson AP, Osborn MF, Taylor-Robinson D. Iron-mediated protection of Neisseria gonorrhoeae against killing by normal human serum. FEMS Microbiology Letters 1978;4:225-7.

19. Wang SP, Holmes KK, Knapp JS, Ott S, Kyzer DD. Immunologic classification of Neisseria gonorrhoeae with microimmunofluorescence. J Immunol 1977;119:795-803.

20. Fine DP, Marney SR, Colley DG, Sergent JS, Des Prez RM. C3 shunt activation in human serum chelated with EGTA. $J$ Immunol 1972;109:807-9.

21. Reyn A, Birch-Anderson A, LaPage SP. An electron microscope study of thin sections of Haemophilus vaginalis (Gardner and Dukes) and some possibly related species. Can J Microbiol 1966;12:1125-36.

22. Criswell BS, Stenback WA, Black SH, Gardner HL. Fine structure of Haemophilus vaginalis. J Bacteriol 1972; 109:930-2. 